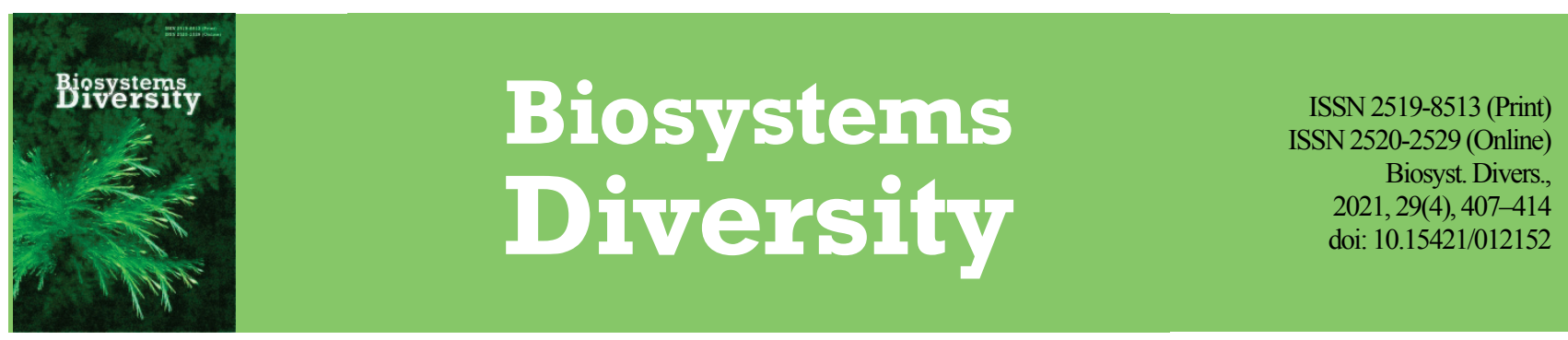

\title{
An overview of helminths of the European fire-bellied toad Bombina bombina (Amphibia, Anura) in the Volga River Basin
}

\author{
I. V. Chikhlyaev*, A. B. Ruchin** \\ *Samara Federal Research Scientific Center of RAS, Institute of Ecology of Volga River Basin of RAS, Togliatti, Russia \\ **Joint Directorate of the Mordovia State Nature Reserve and National Park “Smolny”, Saransk, Russia
}

Article info

Received 22.10.2021

Received in revised form

$$
\text { 24.11.2021 }
$$

Accepted 25.11.2021

\author{
Chikhlyaev, I. V., \& Ruchin, A. B. (2021). An overview of helminths of the European fire-bellied toad Bombina bombina (Amphi- \\ bia, Anura) in the Volga River Basin. Biosystems Diversity, 29(4), 407-414. doi:10.15421/012152
}

Samara Federal Research

Scientific Center of RAS

Institute of Ecology of Volga

River Basin of RAS, Komzina st.

10, Togliatti,445003, Russia.

Tel.: +784-824-893-59.

E-mail:diplodiscus@mail.ru

Joint Directorate of the

Mordovia State Nature Reserve

and National Park "Smolny",

Krasnaya st., 30, Saransk,

430005, Russia.

$\mathrm{Tel} \cdot+783-445-296-48$. E-mail:

ruchin.alexander@gmail.com

The helminthofauna of Bombina bombina (Linnaeus, 1761) has been studied to an unequal degree in different parts of the habitat. Thus, it has been studied in more detail in the west of its range (in the countries of central and eastern Europe) and in less detail in the center (in Belarus and Ukraine). There were few data on helminths of this host in the east of its range (in Russia). For the first time, an inventory of the helminthofauna in B. bombina was carried out for populations in the Volga River Basin. The results of our own research are presented and supplemented with information from other authors. We summarized scattered data on helminths from 390 specimens of amphibians collected over more than 40 years in the territory of five regions: Kaluga and Samara regions, the Republics of Mordovia, Tatarstan and Bashkortostan. The helminthofauna includes 21 species from three classes: Trematoda (15), Chromadorea (5) and Clitellata (1). For each species, we give the systematic position, localization, places of detection, geographical distribution and characteristics of the life cycle. The leech Helobdella stagnalis (Linnaeus, 1758) was first recorded in the European fire-bellied toad in Europe. Four species of trematodes are new to this amphibian species in Russia: Haematoloechus abbreviatus (Bychowsky, 1932), Paralepoderma cloacicola (Luhe, 1909), larvae, Tylodelphys excavata (Rudolphi, 1803), larvae and Astiotrema monticelli (Stossich, 1904), larvae. Another species of trematode - Strigea strigis (Schrank, 1788), larvae - was first recorded in this host within the boundaries of the Volga Basin. A specific parasite is the trematode Haematoloechus abbreviatus (Bychowsky, 1932). The number and composition of the species of helminths of the European fire-bellied toad vary in different regions; the structure of the helminth fauna is generally stable and includes three groups of species: adult and larval stages of trematodes, adult nematodes-geohelminths. The results of the study create a database for further population studies and contribute to the development of ideas about the distribution and formation of the amphibian helminth fauna in Europe, Russia and the Volga Basin.

Keywords: trematodes; nematodes; leeches; Bombinatoridae; Volga region; Haematoloechus abbreviatus; Helobdella stagnalis.

\section{Introduction}

Speaking of the global threats, the conservation of biological diversity is becoming more and more urgent every year. It means that the hundreds of species and millions of populations are disappearing on a planetary scale. During the last century, 400 vertebrate species have become extinct, which in the normal course of evolution would have taken 10 thousand years (Ceballos, 2015). Another 515 species (1.7\% of the total number of living organisms) are on the verge of extinction (Ceballos et al., 2020). Amphibians are considered the most vulnerable group of vertebrates experiencing a sharp reduction of the range and numbers of populations around the world (Gardner, 2001; Wake \& Vredenburg, 2008; Fayzulin et al., 2018; Litvinchuk \& Kidov, 2018; Kurnaz \& Kutrup 2019). Perhaps a fifth of their species have already become extinct or is close to it. The amphibian crisis is usually associated with the disappearance, degradation and pollution of habitats because of anthropogenic activity (Blaustein \& Kiesecker, 2002; Lebedinskii et al., 2019). According to another version, the global warming and climate change are to blame for this (Tytar et al., 2018).

There are also vulnerable amphibian species in Europe, for example, toads (genus Bombina Oken, 1816). The B. bombina (Linnaeus, 1761) is distributed on the plains of Central and Eastern Europe from Denmark in the west to the Urals in the east. It inhabits the forest zone; in the foreststeppe and steppe prefers floodplain biotopes in river valleys. It has an aquatic lifestyle; inhabits shallow, heated water bodies with standing water (lakes, old trees, swamps), herbaceous flora as well as man-made water bodies: ponds, flooded ditches, quarries, peat bogs. It survives in polluted waters: sedimentation tanks, rice paddies (Kuzmin, 2012). Destruction and drying of water bodies, recreation, water pollution with chemicals (Sayim, 2010), introduction of alien fish species are the most dangerous threats for this species (Pupina et al., 2018).

Among other dangers for amphibians, we should note the emergence of a new type of threat in the XXI century such as infectious diseases caused by parasites - fungi (Narayan et al., 2011; Meurling, 2019; Sewell et al., 2021) and helminths (Jayawardena et al., 2013). The pathogenic effect of helminthic infection in amphibians has a wide range of manifesttations: from a number of skeletal anomalies (Schotthoefer et al., 2003; Szuroczki et al., 2011) and limb malformations (Svinin et al., 2020a, 2020b) till the dysfunction of internal organs (Vedernikov et al., 2020), suppression of behavioral reactions, life instincts and death (Ivanov et al., 2012). Unfortunately, amphibian helminths are not given due attention nowadays, despite the fact that the relevance of research in this direction is obvious.

The helminthofauna of the European fire-bellied toad has been studied to an unequal degree in different parts of its range. It has been studied more detailed in the west (in the countries of central and eastern Europe) (Vojtková \& Roca, 1994, 1996). In the central part of the range, helminths of this species were studied in Belarus (Shimalov, 2008, 2009; Bychkova et al., 2017) and Ukraine (Shevchenko, 1965; Maguza, 1973; Iskova et al., 1995). However, so far, there are few data on helminths of this host in east part of its range in Russia (Ryzhikov et al., 1980). The eastern part of the range is located in the Volga River Basin, which occupies 33\% of the territory of European Russia and almost $13 \%$ of Europe. The Volga River has a length of 3,690 km and a basin area of about 1.4 million $\mathrm{km}^{2}$; it flows from north to south through an entire spectrum of biomes from taiga to semi-desert (Litvinov et al., 2009). The European fire-bellied toad is 
broadly distributed in the floodplain biocenoses of the Volga River basin: from the Kaluga and Moscow regions (Kuzmin, 2008; Dunaev \& Orlova, 2017) in its upper reaches to the environs of Volgograd and the Republic of Kalmykia - in the lower reaches (personal observation).

This research is the first inventory of the helminth fauna of the European fire-bellied toad from the populations in the Volga River Basin and continues a cycle of similar studies of other amphibian species (Chikhlyaev \& Ruchin, 2014, 2021; Chikhlyaev et al., 2016, 2018, 2019a, 2019b).

\section{Material and methods}

The study is based on the results of our own research and information from other authors for the period from 1974 to 2020. The study material consists of data on helminths from 390 specimens of amphibians collected for more than 40 years in the territory of five regions of the Volga Basin: Kaluga and Samara regions, the Republics of Mordovia, Tatarstan and Bashkortostan (Fig. 1).

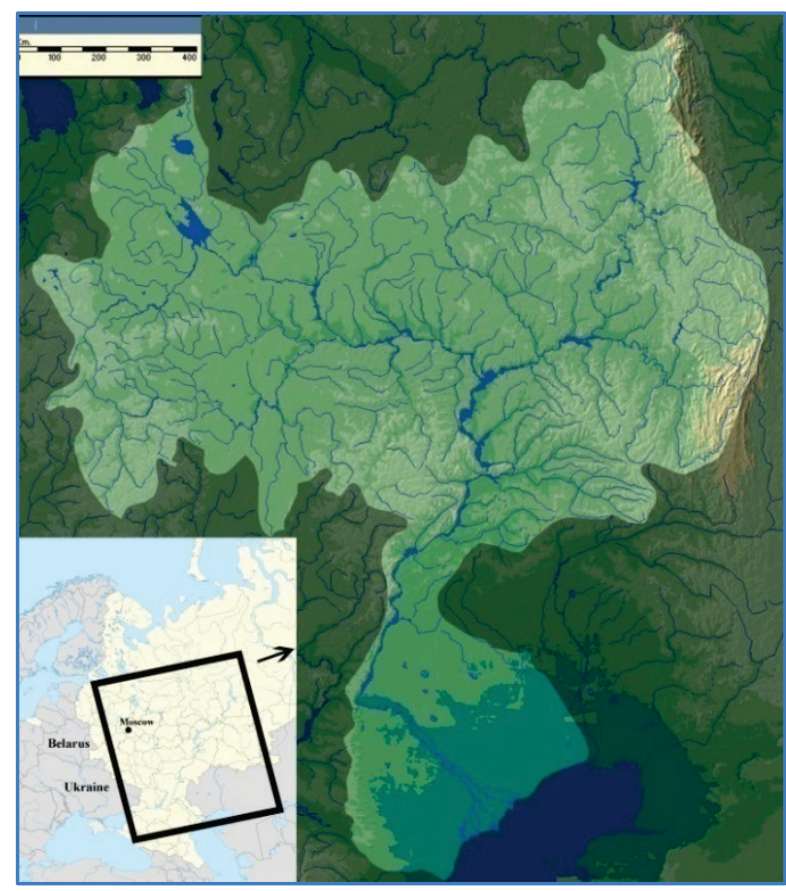

Fig. 1. Location of the Volga Basin

The study of amphibians was carried out using the method of complete helminthological auropsy of vertebrates (Skrjabin, 1928). Collection, fixation and processing of helminthological material were carried out in laboratory conditions (Byhovskaya-Pavlovskaya, 1985). Trematodes were fixed with $70 \%$ ethanol, stained with alum or acetic acid carmine, and after placing in dimethyl phthalate as a clearing agent, they were enclosed in Canadian balsam. Nematodes were straightened by heating, fixed with Barbagallo liquid, clarified in lactic acid and enclosed in glycerin-gelatin. Leeches were fixed with 1-2\% formalin solution, after which they were clarified in glycerin.

The identification of helminths was made according to the reports of Ryzhikov et al. (1980) and Sudarikov et al. (2002). The paper reflects current views on the taxonomy of trematodes (Tkach et al., 2001; Gibson et al., 2002; Olson et al., 2003; Bray et al., 2008) and nematodes (Hodda, 2011). The study was carried out in the laboratory of Population Ecology of the Institute of Ecology of the Volga River Basin of the Russian Academy of Sciences of the Samara Federal Research Scientific Center of the Russian Academy of Sciences (Togliatti, Russia).

\section{Results}

We present an annotated list of helminth species of $B$. bombina from biocenoses of the Volga River basin. For each species, we present data on systematic position, localization, places of detection and geographical distribution. Table 1 shows the composition of helminths of the European fire-bellied toad in different regions of the Volga basin. Table 2 demonstrates the information about the life cycle of the helminths.

Phylum Platyhelminthes Schneider, 1873

Class Trematoda Rudolphi, 1808

Order Hemiurida Skrjabin et Guschanskaja, 1956

Family Derogenidae Nicoll, 1910

1. Halipegus ovocaudatus (Vulpian, 1859)

Localization: tongue, mouth.

Areas of detection: The Republic of Tatarstan (Shaldybin, 1977) and Samara region (Chikhlyaev, 2009; Fayzulin et al., 2013; Kirillov et al., 2018) (Table 1).

Biology: common parasite of the tongue and mouth of anurans (Anura). Tetraxenic life cycle (Table 2).

Distribution: Europe.

Table 1

Helminths of the European fire-bellied toad Bombina bombina in the Volga Basin regions

\begin{tabular}{lccccc}
\hline \multicolumn{1}{c}{ Helminth species } & KL & MR & SM & TT & BS \\
\hline Halipegus ovocaudatus & - & - & + & + & - \\
Diplodiscus subclavatus & + & - & + & + & - \\
Gorgodera cygnoides & - & + & + & - & + \\
Gorgoderina vitelliloba & - & - & + & + & + \\
Opisthioglyphe ranae & - & - & + & + & + \\
Haematoloechus asper & - & - & + & + & - \\
Haematoloechus abbreviatus & + & + & + & - & - \\
Haematoloechus variegatus & - & - & + & + & + \\
Pleurogenes claviger & - & - & - & + & - \\
Pleurogenoides medians & - & - & - & - & + \\
Paralepoderma cloacicola, larvae & - & - & + & - & - \\
Strigea strigis, larvae & + & - & + & - & - \\
Strigea sphaerula, larvae & + & - & + & - & + \\
Tylodelphys excavata, larvae & + & + & + & - & - \\
Astiotrema monticelli, larvae & - & - & + & - & - \\
Rhabdias bufonis & - & - & + & + & + \\
Oswaldocruzia filiformis & - & - & + & - & + \\
Aplectana acuminata & - & - & - & + & - \\
Cosmocerca ornata & + & + & + & + & - \\
Cosmocerca commutata & - & - & - & + & - \\
Helobdella stagnalis & - & - & + & - & - \\
\hline Species in total & $6[3]$ & $4[1]$ & $17[6]$ & 11 & $8[1]$ \\
Trematoda & $5[3]$ & $3[1]$ & $13[6]$ & 7 & $6[1]$ \\
Chromadorea & 1 & 1 & 3 & 4 & 2 \\
Clitellata & - & - & 1 & - & - \\
Examined, specimens & 37 & 15 & 235 & 36 & 67 \\
\hline Notes: KI - Kaluga & & & & & \\
\hline
\end{tabular}

Notes: KL - Kaluga region (Chikhlyaev et al., 2019; our data); MR - The Republic of Mordovia (Chikhlyaev et al., 2015; Ruchin et al., 2016; our data); SM - Samara region (Evlanov et al., 2001, 2002; Chikhlyaev, 2004, 2009, 2019; Kirillov \& Chikhlyaev, 2011; Fayzulin et al., 2013; Kirillov et al., 2018; our data); TT - The Republic of Tatarstan (Shaldybin, 1977; Smirnova \& Sizova, 1978; Smirnova et al., 1987); BS - The Republic of Bashkortostan (Ayupov et al., 1974; Bayanov, 1992; Yumagulova, 2000; Bayanov et al., 2015); "+" - helminth detected; "-" - no helminth detected.

Order Paramphistomida Skrjabin et Schulz, 1937

Family Diplodiscidae Cohn, 1904

2. Diplodiscus subclavatus (Pallas, 1760)

Localization: rectum, small intestine.

Areas of detection: Kaluga (Chikhlyaev et al., 2019) and Samara (Chikhlyaev, 2004, 2009; Kirillov \& Chikhlyaev, 2011; Fayzulin et al., 2013; Kirillov et al., 2018) regions, the Republic of Tatarstan (Shaldybin, 1977; Smirnova \& Sizova, 1978; Smimova et al., 1987) (Table 1).

Biology: a common parasite of the intestines of amphibians (Amphibia). Dixenic life cycle (Table 2).

Distribution: cosmopolite.

Order Fasciolida Skrjabin et Schulz, 1935

Family Gorgoderidae Looss, 1899

3. Gorgodera cygnoides (Zeder, 1800)

Localization: bladder. 
Table 2

Life cycles of helminths of the European fire-bellied toad (Bombina bombina)

\begin{tabular}{|c|c|c|}
\hline Helminths & Life cycle & Autors \\
\hline Halipegus ovocaudatus (Vulpian, 1859) & 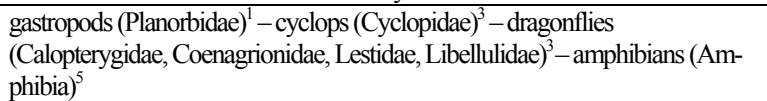 & Keshemir, 1976 \\
\hline Diplodiscus subclavatus (Pallas, 1760) & gastropods (Planorbidae) ${ }^{1}-$ amphibians (Amphibia) $)^{5}$ & Skrjabin, 1949; Grabda-Kazubska, 1980 \\
\hline Gorgodera cygnoides (Zeder, 1800) & bivalves (Sphaeriidae) ${ }^{1}$-dragonflies (Corduliidae) $)^{3}-$ frogs $(\text { Ranidae) })^{5}$ & Pigulevsky, 1952 \\
\hline Gorgoderina vitelliloba (Olsson, 1876) & bivalves $(\text { Sphaeriidae })^{1}-$ tadpoles, alderflies ${ }^{3}$ - anurans (Anura) $)^{5}$ & $\begin{array}{l}\text { Pigulevsky, 1953; Vojtková, 1974; } \\
\text { Kalabekov, } 1976\end{array}$ \\
\hline Opisthioglyphe ranae (Frölich, 1791) & $\begin{array}{l}\text { gastropods (Lymnaeidae) })^{1} \text { - gastropods (Lymnaeidae), tadpoles (Anura) }{ }^{3}- \\
\text { anurans (Anura) }\end{array}$ & $\begin{array}{l}\text { Dobrowolsky, 1965a; Grabda-Kazubska, } \\
1969\end{array}$ \\
\hline Paralepoderma cloacicola (Lühe, 1909), larvae & gastropods (Planorbidae) ${ }^{1}-$ anurans $(\text { Anura })^{3}-$ snakes $(\text { Colubridae })^{5}$ & Dobrowolsky, 1969; Grabda-Kazubska, 1975 \\
\hline Haematoloechus asper Looss, 1899 & $\begin{array}{l}\left.\text { gastropods (Planorbidae) }{ }^{1} \text { - dragonflies (Calopterygidae, Lestidae) }\right)^{3} \text { - anurans } \\
\text { (Anura) })^{5}\end{array}$ & Dobrowolsky, $1965 b$ \\
\hline Haematoloechus abbreviatus Looss, 1899 & $\begin{array}{l}\text { gastropods (Planorbidae) }{ }^{1}-\text { mosquitoes (Culicidae), dragonflies } \\
\left.\text { (Calopterygidae, Libellulidae) })^{3}-\text { anurans (Anura) }\right)^{5}\end{array}$ & Skrjabin \& Antipin, 1962; Thiel, 1930 \\
\hline Haematoloechus variegatus (Rudolphi, 1819) & $\begin{array}{l}\text { gastropods (Planorbidae) }{ }^{1}-\text { mosquitoes (Culicidae), dragonflies } \\
\left.(\text { Calopterygidae, Libellulidae) })^{3}-\text { anurans (Anura) }\right)^{5}\end{array}$ & Skrjabin \& Antipin, 1962; Thiel, 1930 \\
\hline Pleurogenes claviger (Rudolphi, 1819) & $\begin{array}{l}\text { gastropods (Bithyniidae) }{ }^{1} \text { - dragonflies, bugs, mayflies, caddis flies, alderflies, } \\
\text { crustaceans (Gammaridae, Asellidae) })^{3} \text { - anurans (Anura) }{ }^{5}\end{array}$ & Khotenovsky, 1970; Grabda-Kazubska, 1971 \\
\hline Pleurogenoides medians (Olsson, 1876) & $\begin{array}{l}\text { gastropods (Bithyniidae) } 1 \text { - dragonflies, bugs, mayflies, caddis flies, alderflies, } \\
\text { mosquitoes, crustaceans (Gammaridae, Asellidae) })^{3} \text {-anurans (Anura) } \\
\left.\left.\text { gastropods (Planorbidae) })^{1} \text { - tadpoles (Anura) }\right)^{2} \text {-anurans (Anura) }\right)^{3,4}-\text { snakes }\end{array}$ & Neuhaus, 1940; Khotenovsky, 1970 \\
\hline Strigea strigis (Schranck, 1788), larvae & $\begin{array}{l}\text { (Colubridae), mammals (Eulipotyphla, Mustelidae, Canidae) }{ }^{4} \text { - owls (Strigi- } \\
\text { formes) }^{5}\end{array}$ & Odening, 1966a, 1967; Sudarikov, 1984 \\
\hline Strigea sphaerula (Rudolphi, 1803), larvae & $\begin{array}{l}\text { gastropods }(\text { Planorbidae })^{1}-\text { tadpoles }(\text { Anura })^{2} \text { - anurans }(\text { Anura })^{3,4}-\text { snakes } \\
(\text { Colubridae })^{4}-\text { crows }(\text { Corvidae })^{5}\end{array}$ & Odening, 1966b, 1967; Sudarikov, 1984 \\
\hline Tylodelphys excavata (Rudolphi, 1803), larvae & gastropods (Planorbidae) ${ }^{1}$ - frogs (Anura) $)^{3}-$ long-legged birds (Ciconiiformes) & Sudarikov, 1960 \\
\hline Astiotrema monticelli Stossich, 1904, larvae & gastropods (Bithyniidae) ${ }^{1}$ - anurans (Anura) $)^{3}-$ snakes (Colubridae, Viperidae) $)^{5}$ & Shevchenko \& Vergun, 1960; Sharpilo, 1976 \\
\hline Rhabdias bufonis (Schranck, 1788) & soil - oligochaetes, gastropods ${ }^{4}-$ anurans $\left._{(\text {Anura }}\right)^{5}$ & $\begin{array}{l}\text { Schaake, 1931; Savinov, 1963; Hartwich, } \\
1975\end{array}$ \\
\hline Oswaldocruzia filiformis (Goeze, 1782) & soil-amphibians (Amphibia) ${ }^{5}$ & Hendrix, 1983; Moravec \& Vojtkova, 1975 \\
\hline Aplectana acuminata (Schrank, 1788) & unknown & none \\
\hline Cosmocerca ornata (Duiardin, 1845) & water-anurans (Anura) $)^{5}$ & Kirillova \& Kirillov, 2021 \\
\hline Cosmocerca commutata (Diesing, 1851) & soil-anurans (Anura) ${ }^{1,5}$ & Skrjabin et al., 1961; Yumagulova, 1999 \\
\hline Helobdella stagnalis (Linnaeus, 1758) & water-insects, crustaceans, oligochaetes, leeches ${ }^{5}$ & Sawyer, 1986 \\
\hline
\end{tabular}

Note: ${ }^{1}$-intermediate host; ${ }^{2}$-intercalary host; ${ }^{3}$-additional host ${ }^{4}$ - paratenic host $;{ }^{5}$-definitive host.

Areas of detection: The Republics of Mordovia (Chikhlyaev et al., 2015; Ruchin et al., 2016) and Bashkortostan (Bayanov, 1992; Yumagulova, 2000), Samara region (Chikhlyaev, 2009; Fayzulin et al., 2013; Kirillov et al., 2018) (Table 1)

Biology: common parasite of the bladder of anurans (Anura). Trixenic life cycle (Table 2).

Distribution: Palearctic.

4. Gorgoderina vitelliloba (Olsson, 1876)

Localization: bladder.

Areas of detection: The Republics of Tatarstan (Shaldybin, 1977; Smirnova et al., 1987) and Bashkortostan (Bayanov, 1992; Yumagulova, 2000), Samara region (Chikhlyaev, 2009; Kirillov \& Chikhlyaev, 2011; Fayzulin et al., 2013; Kirillov et al., 2018) (Table 1).

Biology: common parasite of the bladder of anurans (Anura). Trixenic life cycle (Table 2).

Distribution: Palearctic.

Order Plagiorchiida La Rue, 1957

Family Telorchiidae Looss, 1899

5. Opisthioglyphe ranae (Frohlich, 1791)

Localization: small intestine.

Areas of detection: The Republics of Tatarstan (Shaldybin, 1977; Smirnova et al., 1987) and Bashkortostan (Bayanov, 1992; Yumagulova, 2000), Samara region (Chikhlyaev, 2009; Fayzulin et al., 2013; Kirillov et al., 2018) (Table 1).

Biology: a common intestinal parasite of amphibians (Amphibia) at the adult stage. Trixenic life cycle (Table 2).

Distribution: Palearctic.

Family Leptophallidae Dayal, 1938

6. Paralepoderma cloacicola (Luhe, 1909), larvae

Localization: musculature, mesentery.

Areas of detection: Samara region (Evlanov et al., 2001, 2002; Chik- hlyaev, 2004, 2009; Kirillov \& Chikhlyaev, 2011; Fayzulin et al., 2013; Kirillov et al., 2018) (Table 1). This is the first finding of the parasite in the European fire-bellied toad in Russia and the Volga basin.

Biology: in the metacercariae stage, a common parasite of the musculature and mesentery of amphibians (Amphibia). Trixenic life cycle (Table 2).

Distribution: Palearctic.

Family Haematoloechidae Freitas et Lent, 1939

7. Haematoloechus abbreviatus (Bychowsky, 1932)

Localization: lungs.

Areas of detection: Kaluga (Chikhlyaev et al., 2019) and Samara (Chikhlyaev, 2019) regions, the Republics of Mordovia (Chikhlyaev et al., 2015; Ruchin et al., 2016) (Table 1).

Biology: specific amphibian lung parasite of the genus Bombina (Oken, 1816). Trixenic life cycle (Table 2).

Distribution: Europe.

8. Haematoloechus asper Looss, 1899

Localization: lungs.

Areas of detection: The Republic of Tatarstan (Shaldybin, 1977; Smirnova et al., 1987) and Samara region (Chikhlyaev, 2004, 2009; Fayzulin et al., 2013) (Table 1).

Biology: typical parasite of frog (Ranidae) lungs. Trixenic life cycle (Table 2).

Distribution: Europe.

9. Haematoloechus variegatus (Rudolphi, 1819)

Localization: lungs.

Areas of detection: Samara (Chikhlyaev, 2009; Kirillov \& Chikhlyaev, 2011; Fayzulin et al., 2013; Kirillov et al., 2018) region, the Republics of Tatarstan (Shaldybin, 1977; Smirnova \& Sizova, 1978; Smirnova et al., 1987) and Bashkortostan (Ayupov et al., 1974; Bayanov, 1992; Yumagulova, 2000) (Table 1).

Biology: common parasite of anurans (Anura) lungs. Trixenic life cycle (Table 2). 


\section{Distribution: Palearctic.}

Family Lecithodendridae Odhner, 1911

10. Pleurogenes claviger (Rudolphi, 1819)

Localization: small intestine.

Areas of detection: The Republic of Tatarstan (Shaldybin, 1977; Smirnova et al., 1987) (Table 1).

Biology: a common parasite of the intestines of amphibians (Amphi-

bia). Trixenic life cycle (Table 2).

Distribution: cosmopolite.

11. Pleurogenoides medians (Olsson, 1876)

Localization: small intestine.

Areas of detection: The Republic of Bashkortostan (Ayupov et al.,

1974; Bayanov, 1992; Yumagulova, 2000) (Table 1).

Biology: a common parasite of the intestines of anurans (Anura). Trixenic life cycle (Table 2).

Distribution: Palearctic.

Order Strigeidida (La Rue, 1926)

Family Strigeidae Railliet, 1919

12. Strigea strigis (Schrank, 1788), larvae

Localization: serous coat of inner organs, mesentery, musculature.

Areas of detection: Kaluga (Chikhlyaev et al., 2019) and Samara (Chikhlyaev, 2004, 2009; Fayzulin et al., 2013; Kirillov et al., 2018) regions (Table 1). The parasite has been recorded for the first time in the European fire-bellied toad in the Volga basin.

Biology: in the metacercariae stage, a common parasite of the body cavity, internal organs, musculature and mesentery of anurans (Anura). Tetraxenic life cycle (Table 2).

Distribution: Palearctic.

13. Strigea sphaerula (Rudolphi, 1803), larvae

Localization: serous coat of inner organs, pericardium, musculature.

Areas of detection: Kaluga (Chikhlyaev et al., 2019) and Samara (Chikhlyaev, 2004, 2009; Fayzulin et al., 2013; Kirillov et al., 2018) regions, the Republic of Bashkortostan (Ayupov et al., 1974; Bayanov, 1992; Yumagulova, 2000) (Table 1)

Biology: in the metacercariae stage, a common parasite of the body cavity, internal organs, musculature and mesentery of anurans (Anura). Tetraxenic life cycle (Table 2)

Distribution: Europe.

Family Diplostomidae Poirier, 1886

14. Tylodelphys excavata (Rudolphi, 1803), larvae

Localization: spinal cord canal.

Areas of detection: Kaluga (Chikhlyaev et al., 2019) and Samara (Evlanov et al., 2001, 2002; Chikhlyaev, 2004, 2009; Kirillov \& Chikhlyaev, 2011; Fayzulin et al., 2013; Kirillov et al., 2018) regions, the Republic of Mordovia (Chikhlyaev et al., 2015; Ruchin et al., 2016) (Table 1). The parasite was first noted in the European fire-bellied toad in Russia and the Volga basin.

Biology: typical parasite of the spinal canal of anurans (Ranidae, Discoglossidae) at the metacercariae stage. Trixenic life cycle (Table 2).

Distribution: Palearctic

Incertae sedis group

15. Astiotrema monticelli Stossich, 1904, larvae

Localization: intestine mesentery.

Areas of detection: Samara region (Chikhlyaev, 2004; Kirillov \& Chikhlyaev, 2011; Fayzulin et al., 2013; Kirillov et al., 2018) (Table 1). This is a new parasite for the European fire-bellied toad of Russia and the Volga basin.

Biology: in the metacercariae stage, the common parasite of the mesentery and body cavity of anurans (Anura). Trixenic life cycle (Table 2).

Distribution: Europe.

Phylum Nematoda Cobb, 1932

Class Chromadorea Inglis, 1983

Order Panagrolaimida Hodda, 2007

Family Rhabdiasidae Railliet, 1915
16. Rhabdias bufonis (Schrank, 1788)

Localization: lungs.

Areas of detection: The Republics of Tatarstan (Shaldybin, 1977; Smirnova et al., 1987) and Bashkortostan (Ayupov et al., 1974; Yumagulova, 2000), Samara region (Chikhlyaev, 2009, 2019; Fayzulin et al., 2013; Kirillov et al., 2018) (Table 1).

Biology: common parasite of anurans (Anura) lungs. Monoxenic life cycle (geohelminth) (Table 2).

Distribution: Holarctic.

Family Trichostrongylidae Leiper, 1908

17. Oswaldocruzia filiformis (Goeze, 1782)

Localization: small intestine.

Areas of detection: Samara region (Chikhlyaev, 2019) and the Republic of Bashkortostan (Bayanov, 1992; Yumagulova, 2000) (Table 1).

Biology: a common parasite of the intestines of amphibians (Amphibia). Monoxenic life cycle (geohelminth) (Table 2).

Distribution: Palearctic.

Order Spirurida Railliet, 1914

Family Cosmocercidae Travassos, 1925

18. Aplectana acuminata (Schrank, 1788)

Localization: intestine.

Areas of detection: The Republic of Tatarstan (Shaldybin, 1977; Smirnova \& Sizova, 1978; Smirnova et al., 1987) (Table 1)

Biology: typical intestinal parasite of tadpoles, less commonly adult anurans (Anura). Monoxenic life cycle (geohelminth, Table 2).

Distribution: Europe.

19. Cosmocerca ornata (Dujardin, 1845)

Localization: rectum.

Areas of detection: Kaluga (Chikhlyaev et al., 2019) and Samara (Chikhlyaev, 2004, 2009, 2019; Fayzulin et al., 2013; Kirillov et al., 2018) regions, the Republics of Mordovia (Chikhlyaev et al., 2015; Ruchin et al., 2016) and Tatarstan (Shaldybin, 1977; Smirnova \& Sizova, 1978; Smirnova et al., 1987) (Table 1).

Biology: a common parasite of the intestines of amphibians (Amphi-

bia). Monoxenic life cycle (geohelminth) (Table 2).

Distribution: Europe.

20. Cosmocerca commutata (Diesing, 1851)

Localization: rectum.

Areas of detection: The Republic of Tatarstan (Shaldybin, 1977; Smirnova \& Sizova, 1978).

Biology: In the adult stage of development a specific parasite of the intestines of green toads (Bufotes viridis Laurenti, 1768, Table 1). Monoxenic life cycle (geohelminth) with obligatory amphixeny (Table 2).

Distribution: Palearctic.

Phylum Annelida Lamarck, 1809

Class Clitellata Michaelsen, 1919

Order Rhynchobdellida Blanchard, 1894

Family Glossiphonidae Vaillant, 1890

21. Helobdella stagnalis (Linnaeus, 1758)

Localization: skin.

Areas of detection: The Samara region (Chikhlyaev, 2004; Kirillov \& Chikhlyaev, 2011; Fayzulin et al., 2013; Kirillov et al., 2018) (Table 1). This is the first and the only find of leeches in the European fire-bellied toad in Europe, Russia and the Volga basin. There were no deviations from the original description. Earlier discoveries have been made in the yellow-bellied toad (Bombina variegata (Linnaeus, 1758)) in Bosnia and Herzegovina (Zimić, 2015), the common frog (Rana temporaria Linnaeus, 1758) in Northwestern Italy (Tiberti \& Gentilli, 2010) and the palmate newt (Lissotriton helveticus Razoumowsky, 1789) in the Netherlands (Stark et al., 2017).

Biology: accidental parasite of amphibians (Amphibia). A common parasite (other reports say it is a predator, sucking out the body fluids and soft parts of its prey) of freshwater molluscs, arthropods, oligochaetes and other leeches. Monoxenic life cycle (Table 2).

Distribution: Cosmopolite. 


\section{Discussion}

Therefore, there are currently known 21 species of helminths parasitizing in B. bombina in the Volga River basin. Taxonomically, they belong to 17 genera, 13 families, 8 orders and 3 classes: Trematoda -15 , Chromadorea -5 , Clitellata -1 . The leech Helobdella stagnalis (Linnaeus, 1758) was first recorded in this amphibian species in Europe. Four species of trematodes are new to the European fire-bellied toad in Russia: Haematoloechus abbreviatus (Bychowsky, 1932), Paralepoderma cloacicola (Luhe, 1909), larvae, Tylodelphys excavata (Rudolphi, 1803), larvae and Astiotrema monticelli Stossich, 1904, larvae. Another species of trematode - Strigea strigis (Schrank, 1788), larvae - was first recorded in this host within the boundaries of the Volga Basin.

Species of helminths differ in the degree of hostal specificity. Most of the species (18) of trematodes and nematodes are poly-hostal parasites of tailless amphibians. The nematode Cosmocerca commutata is a monohost-specific parasite of Bufotes viridis Laurenti, 1768. However, according to some scientists, Shaldybin (1977) and Smimova \& Sizova (1978), it occurs in amphibians of other genera and families. The leech Helobdella stagnalis is an obligate ectoparasite of freshwater invertebrates. This find can be regarded as a rare example of accidental parasitism in the conditions of joint habitation of the natural hosts of leeches in the same water bodies.

The trematode Haematoloechus abbreviatus (Bychowsky, 1932) is a specific oligohostal parasite of amphibians of the genus Bombina (Oken, 1816). Previously known as a subspecies of Pneumonoeces variegatus abbreviatus Bychowsky, 1932, now it is listed as an independent species. This is due not only to anatomical differences (Skryabin \& Antipin, 1962), but also to the results of molecular genetic analysis (Leon-Regagnon \& Brooks, 2003).

The European fire-bellied toad performs a different role in relation to certain helminths species. For example, it is the definitive host for species at the adult stage of development (12); additional or reservoir host for metacercariae of trematodes (5) (Table 1). Another three species of helminths ( $G$. vitelliloba, O. ranae and C. commutata) parasitize in the body of amphibians during their larval and adult stages of the development simultaneously. This characterizes the European fire-bellied toad as an amphixenic host.

The number of helminth species in amphibians in some regions of the Volga Basin is not the same and decreases in the following order: Samara region (17 species) - Republic of Tatarstan (11) - Republic of Bashkortostan (8) - Kaluga Region (6) - Republic of Mordovia (4) (Table 1). The number of helminth species is influenced by the following factors: the volume of studied amphibians, the type and nature of water bodies, the geographical location and climate of the area, the level of anthropogenic impact.

The composition of helminths of the European fire-bellied toad also differs in different regions of the Volga Basin. None out of 21 helminth species were observed in all the samples. The reason for this is probably the biotopic features in a particular region of the Volga Basin. Only one species, the nematode $C$. ornata, was found in four of the five regions. It is a characteristic parasite of aquatic amphibian species. Infection with it occurs in the water, when the host comes into contact with free-floating invasive larvae. Most helminth species (H. abbreviatus, D. subclavatus, G. cygnoides, G. vitelliloba, O. ranae, S. sphaerula, larvae, T. excavata, larvae and $R h$. bufonis) were found in three regions. This group of species can be characterized as common and widespread parasites of this host. Helminths found only in two regions (H. ovocaudatus, H. variegatus, H. asper, $S$. strigis, larvae and $O$. filiformis) are rare and occur sporadically. The remaining trematodes (P. claviger, $P$. medians, $P$. cloacicola, larvae and A. monticelli, larvae), nematodes (A. acuminata, C. commuta$t a)$ and leech (H. stagnalis) were recorded strictly locally. These species of helminths are not characteristic of the European fire-bellied toad and are among the accidental parasites.

\section{Conclusion}

The biology and ecology of the European fire-bellied toad has a number of distinctive features:
1) aquatic lifestyle in small, shallow and overgrown floodplain water bodies with stagnant water;

2) feeding mainly on small aquatic invertebrates (mollusks, diptera larvae);

3) rarely visits land, except for migrations to wintering sites and reverse migrations to water bodies in spring;

4) they do not feed during mating.

These factors determine the species composition and structure of the helminthofauna for this amphibian species.

The structure of the helminthofauna of the European fire-bellied toad is mainly stable in different regions and includes three groups of species: 1) adult biohelminths (trematodes); 2) adult geohelminths (nematodes); 3) larval biohelminths (trematodes). Most adult trematodes (10 species) are common parasites of this host, with characteristic low rates of invasion. Trematode infestation is limited by the small size of the amphibian's body and mouth, which narrows the spectrum of its nutrition. Nematodes (5), except for $C$. ornata, are rare and have low invasion values. Most species of nematodes develop in soil, which is at odds with the aquatic lifestyle of the European fire-bellied toad. Helminths at the larval stage (5) are recorded sporadically with different indicators of invasion. The determining factor for them is the presence or absence of predators (their definitive hosts) and the degree of habitat transformation.

The European fire-bellied toad performs a special biocenotic role, being a valuable food object for a number of aquatic and near-water predators. Pike, green frogs, grass snakes, marsh turtles, herons and some duck species, insectivorous mammals and mustelids eat adults. The larval stages of helminths use trophic connections to circulate development and indicate the presence of certain predators in the biocenosis. For example, the findings of metacercariae of trematodes $P$. cloacicola and $A$. monticelli indicate grass snakes; $S$. strigis, $S$. sphaerula and $T$. excavata indicate owls, ravens and herons, respectively. In addition, this amphibian species is able to transmit metacercariae of trematodes of the family Strigeidae to their reservoir hosts: vipers and lizards, diurnal birds of prey, gulls and chickens, rodents and canine mammals. The results of the study create a database for further population studies and contribute to the development of ideas about the distribution and formation of the amphibian helminth fauna in Europe, Russia and the Volga basin.

The authors are grateful to the staff of the Institute of Ecology of the Volga River Basin of the Russian Academy of Sciences (Samara Federal Research Scientific Center of the Russian Academy of Sciences, Russia) A. I. Fayzulin (Togliatti), V. A. Korzikov (Kaluga) for their assistance in collecting the material. The research was carried out on thesubject of research of the Institute of Ecology of the Volga River Basin of the Russian Academy of Sciences - Branch of the Samara Federal Research Center of the Russian Academy of Sciences AAAA-A17-1171120400403 "Assessment of modern biodiversity and forecast of its change for the ecosystems of the Volga basin in the conditions of their natural and anthropogenic transformation" (theme 52 "Biological diversity").

\section{References}

Ayupov, K. V., Valiullin, S. M., Khaziev, G. Z., Bayanov, M. G., Kazadaev, V. I., \& Antonov, P. P. (1974). Gel'minty zhivotnykh, cheloveka i rastenij v Bashkirskoj ASSR [Helminths of animals, humans and plants in the Bashkir ASSR]. In: Helminths of animals, humans and plants in the Southern Urals. Issue 1. Bashkir Branch of the USSR Academy of Sciences, Ufa. Pp. 8-28 (in Russian).

Bayanov, M. G. (1992). Gel'minty zemnovodnykh Bashkirii [Helminths of amphibians in Bashkortostan]. In: Problems of animal ecology of Southern Ural. Issue 5. Bashkir State University, Ufa. Pp. 2-10 (in Russian).

Bayanov, M. G., Kniss, V. A., \& Khabibullin, V. F. (2015). Katalog zhivotnykh Bashkortostana [Catalogue of animals of Bashkortostan]. Bashkir State University Press, Ufa (in Russian).

Blaustein, A. R., \& Kiesecker, J. M. (2002). Complexity in conservation: Lessons from the global decline of amphibian populations. Ecology Letters, 5, 597-608.

Bray, R. A., Gibson, D. I., \& Jones, A. (2008). Keys to the Trematoda. Volume 3. CABI Publishing and The Natural History Museum, London.

Bychkova, E. I., Akimova, L. N., Degtyarik, S. M., \& Yakovich, M. M. (2017). Gel'minty pozvonochnykh zhivotnykh i cheloveka na territorii Belarusi [Helminths of vertebrate animals and humans in Belarus]. Belaruskaya Navuka, Minsk (in Russian). 
Byhovskaya-Pavlovskaya, I. E. (1985). Parazity ryb. Rukovodstvo po izucheniyu [Parasites of fishes, a study guide]. Nauka, Leningrad (in Russian).

Ceballos, G., Ehrlich, P. R., \& Raven, P. H. (2020). Vertebrates on the brink as indicators of biological annihilation and the sixth mass extinction. Proceedings of the National Academy of Sciences, 117(24), 13596-13602.

Ceballos, G., Ehrlich, P. R., Barnosky, A. D., García, A., Pringle, R. M., \& Palmer, T. M. (2015). Accelerated modern human-induced species losses: Entering the sixth mass extinction. Science Advances, 1(5), e1400253.

Chikhlyaev, I. V. (2004). Gel'minty zemnovodnykh (Amphibia) Srednego Povolzh'ya (fauna, ekologiya) [Amphibian helminths (Amphibia) of the Middle Volga Region (fauna, ecology)]. Institute of Ecology of the Volga Basin RAS, Togliatti (in Russian)

Chikhlyaev, I. V. (2009). Gel'mintofauna krasnobryukhoj zherlyanki Bombina bombina (Amphibia: Anura) Samarskoj Luki [The helminth fauna of the fire-bellied toad Bombina bombina (Amphibia: Anura) of Samarskaya Luka]. Samarskaya Luka, 18(4), 183-188 (in Russian).

Chikhlyaev, I. V. (2019). O gel'mintakh krasnobryukhoj zherlyanki Bombina bombina (Linnaeus, 1761) v g. Tol'yatti (Samarskaya oblast') [On helminths of the fire-bellied toad Bombina bombina (Linnaeus, 1761) in Togliatti (Samara Region)]. In: Ecological collection 7: Proceedings of young scientists. Anna, Togliatti. Pp. 500-502 (in Russian).

Chikhlyaev, I. V., \& Ruchin, A. B. (2014). The helminth fauna study of European common brown frog (Rana temporaria Linnaeus, 1758) in the Volga basin. Acta Parasitologica, 59(3), 459-471.

Chikhlyaev, I. V., \& Ruchin, A. B. (2021). An overview of the helminths of moor frog Rana arvalis Nilsson, 1842 (Amphibia, Anura) in the Volga basin. Diversity, 13,61 .

Chikhlyaev, I. V., Korzikov, V. A., \& Fayzulin, A. I. (2019). Materialy k gel'mintofaune krasnobryukhoj zherlyanki Bombina bombina (Linnaeus, 1761) (Amphibia, Anura) v Kaluzhskoj oblasti [Materials on the helminth fauna of the firebellied toad Bombina bombina (Linnaeus, 1761) (Amphibia: Anura) in the Kaluga region]. Bulletin of the Samara Scientific Centre of RAS, 21(2), 164-157 (in Russian).

Chikhlyaev, I. V., Ruchin, A. B., \& Fayzulin, A. I. (2015). Gel'minty beskhvostykh zemnovodnykh (Anura, Amphibia) Mordovskogo zapovednika [Helminths of tailless amphibians (Anura, Amphibia) of the Mordovia nature reserve]. Proceedings of Mordovia State Nature Reserve, 14, 376-388 (in Russian).

Chikhlyaev, I. V., Ruchin, A. B., \& Fayzulin, A. I. (2016). The helminth fauna study of European common toad Bufo bufo (Linnaeus, 1758) in the Volga basin. Nature Environment and Pollution Technology, 15(3), 1103-1109.

Chikhlyaev, I. V., Ruchin, A. B., \& Fayzulin, A. I. (2018). Short communication: An overview of the trematodes fauna of pool frog Pelophylax lessonae (Camerano, 1882 ) in the Volga basin, Russia: 1. Adult stages. Nusantara Bioscience, 10(4), 256-262.

Chikhlyaev, I. V., Ruchin, A. B., \& Fayzulin, A. I. (2019a). Short communication: An overview of the trematodes fauna of pool frog Pelophylax lessonae (Camerano, 1882) in the Volga basin, Russia: 2. Larval stages. Nusantara Bioscience, 11(1), 106-111.

Chikhlyaev, I. V., Ruchin, A. B., \& Fayzulin, A. I. (2019b). Parasitic nematodes of pool frog (Pelophylax lessonae) in the Volga basin. Journal MVZ Cordoba, 24(3), 7314-7321.

Dobrowolsky, A. A. (1965a). Some information about the life cycle of the trematode Opisthioglyphe ranae (Froelich, 1791) (Plagiorchiidae). Helminthologia, 3, 205-221.

Dobrowolsky, A. A. (1965b). Zhiznennyj tsikl Pneumonoeces asper Looss, 1899 (Plagiorchiidae, Pneumonoecinae) [The life cycle of Pneumonoeces asper Looss, 1899 (Plagiorchiidae, Pneumonoecinae)]. Proceedings of the Scientific Conference of the All-Union Society of Helminthologists. Part 4. USSR Academy of Sciences, Moscow. Pp. 59-64 (in Russian).

Dobrowolsky, A. A. (1969). Zhiznennyj tsikl Paralepoderma cloacicola (Lühe, 1909) Dollfus, 1950 (Trematoda, Plagiorchiidae) [The life cycle of Paralepoderma cloacicola (Lühe, 1909) Dollfus, 1950 (Trematoda, Plagiorchiidae)]. Leningrad University Bulletin, 9, 28-38 (in Russian).

Dunaev, E. A., \& Orlova, V. F. (2017). Zemnovodnye i presmykayushhiesya Rossii: Atlas-opredelitel' [Amphibians and reptiles of Russia: Identification Atlas. 2nd Edition]. Phyton XXI Publishing, Moscow (in Russian).

Evlanov, I. A., Kirillov, A. A., Chikhlyaev, I. V., Guzova, N. Y., \& Zhiltsova, L. V. (2001). Parazity pozvonochnykh zhivotnykh Samarskoj oblasti. Chast' 1: Sistematicheskij katalog [Parasites of vertebrates of the Samara region. Part 1: A systematic catalog]. Institute of Ecology of the Volga basin RAS, Togliatti (in Russian).

Evlanov, I. A., Kirillov, A. A., Chikhlyaev, I. V., Guzova, N. Y., \& Zhiltsova, L. V. (2002). Parazity pozvonochnykh zhivotnykh Samarskoj oblasti. Chast' 2: Raspredelenie parazitov po vidam khozyaev [Parasites of vertebrates of the Samara region. Part 2: Distribution of parasites by hosts]. Institute of Ecology of the Volga basin RAS, Togliatti (in Russian).

Fayzulin, A. I., Chikhlyaev, I. V., \& Kuzovenko, A. E. (2013). Amfibii Samarskoj oblasti [Amphibians of the Samara region]. Cassandra, Togliatti (in Russian).
Fayzulin, A. I., Zamaletdinov, R. I., Litvinchuk, S. N., Rosanov, J. M., Borkin, L. J., Ermakov, O. A., Ruchin, A. B., Lada, G. A., Svinin, A. O., Bashinsky, I. V., \& Chikhlyaev, I. V. (2018). Species composition and distributional peculiarities of green frogs (Pelophylax esculentus complex) in protected areas of the Middle Volga Region (Russia). Nature Conservation Research, 3(Suppl. 1), 1-16.

Gardner, T. (2001). Declining amphibian populations: A global phenomenon in conservation biology. Animal Biodiversity and Conservation, 24, 25-44.

Gibson, D. I., Jones, A., \& Bray, R. A. (2002). Keys to the Trematoda. Volume 1. CABI Publishing and The Natural History Museum, London.

Grabda-Kazubska, B. (1969). Studies on abbreviation of the life-cycle in Opisthioglyphe ranae (Froelich, 1791) and O. rastellus (Olsson, 1876) (Trematoda, Plagiorchiidae). Acta Parasitologica Polonica, 16, 20-27.

Grabda-Kazubska, B. (1971). Life cycle of Pleurogenes claviger (Rudolphi, 1819) (Trematoda: Pleurogenidae). Acta Parasitologica Polonica, 19, 337-348.

Grabda-Kazubska, B. (1975). A study of the trematode genus Paralepoderma Dollfus, 1950 (Trematoda: Plagiorchiidae). Acta Parasitologica Polonica, 23, 463- 484.

Grabda-Kazubska, B. (1980). Observations on the life cycle of Diplodiscus subclavatus (Pallas, 1760) (Trematoda, Diplodiscidae). Acta Parasitologica Polonica, 27, 261-271.

Hartwich, G. (1975). Die Tierwelt Deutschlands. I.: Rhabditida und Ascaridida [The animal world of Germany. I.: Rhabditida and Ascaridida]. Mitteilungen aus dem Zoologischen Museum in Berlin, 62. Akademie-Verlag, Berlin (in German).

Hendrix, W. M. L. (1983). Observations of the routes of infection of Oswaldocruzia filiformis (Nematoda, Trichostrongylidae) in amphibian. Zeitschrift für Parasitekunde, 69(1), 119-126.

Hodda, M. (2011). Phylum Nematoda Cobb, 1932. Zootaxa, 3148, 63-95.

Iskova, N. I., Sharpilo, V. P., Sharpilo, V. D., \& Tkach, V. V. (1995). Katalog gel'mintov pozvonochnykh Ukrainy. Trematody nazemnykh pozvonochnykh [Catalogue of helminths of vertebrates of Ukraine. Trematodes of terrestrial vertebrates]. Institute of Zoology named after I. I. Schmalhauzen, Kiev (in Russian).

Ivanov, V. M., Kalmykov, A. P., Semyonova, N. N., Fedorovich, V. V., \& Parshina O. Y. (2012). Izmenenie povedeniya i zhiznesposobnosti ozernykh lyagushek pod vliyaniem gel'mintoznoj invazii [Changes in behavior and viability of marsh frog under the influence of helminthic invasion]. Current Studies in Herpetology, 12, 49-55 (in Russian).

Jayawardena, U. A., Tkach, V. V., Navaratne, A. N., Amerasinghe, P. H., \& Rajakaruna, R. S. (2013). Malformations and mortality in the asian common toad induced by exposure to Pleurolophocercous cercariae (Trematoda: Cryptogonimidae). Parasitology International, 62, 246-252.

Kalabekov, A. (1976). Tsikly razvitiya nekotorykh trematod maloaziatskoj lyagushki (Rana macrocnemis Boul.) [Development cycles of some trematodes of longlegged wood frog (Rana macrocnemis Boul.)]. In: Ecology and biology of animals on the northern slopes Central Caucasus. North Ossetian State University, Ordzhonikidze. Pp. 3 - 42 (in Russian).

Kechemir, N. (1976). Cycle a quatre hotes obligatoires du trematode hemiuride Halipegus ovocaudatus [Four-host cycle of the hemiurid trematode Halipegus ovocaudatus]. Bulletin de la Societe Zoologique de France, 101(5), 1061-1062 (in French).

Khotenovsky, I. A. (1970). Semejstvo Pleurogenidae Looss, 1899 [The family Pleurogenidae Looss, 1899]. In: Trematodes of animals and human. Basics of trematodology. Volume 23. Nauka, Moscow. Pp. 136-297 (in Russian).

Kirillov, A. A., \& Chikhlyaev, I. V. (2011). Gel'mintofauna nizshikh nazemnykh pozvonochnykh (Amphibia, Reptilia) pojmy r. Sok [Helminthofauna of the lower terrestrial vertebrates (Amphibia, Reptilia) of the Sok River floodplain]. In: Peculiarities of freshwater ecosystems of the small rivers of the Volga basin. Cassandra, Togliatti. Pp. 178-184 (in Russian).

Kirillov, A. A., Kirillova, N. Y., \& Chikhlyaev, I. V. (2018). Parazity pozvonochnykh zhivotnykh Samarskoj oblasti [Parasites of vertebrate animals of the Samara Region]. Poliar, Togliatti (in Russian).

Kirillova, N. Y., \& Kirillov, A. A. (2021). Zhiznennyj tsikl parazita amfibij nematody Cosmocerca ornata (Dujardin, 1845) (Nematoda: Cosmocercidae) [The life cycle of Cosmocerca ornata (Dujardin, 1845) (Nematoda: Cosmocercidae) - a parasite of amphibians]. Inland Water Biology, 3, 286-301 (in Russian).

Kurnaz, M., \& Kutrup, B. (2019). New distribution data of the vulnerable Mertensiella caucasica from Gümüşhane, Turkey. Nature Conservation Research, 4(1), 109-111.

Kuzmin, S. L. (2012). Zemnovodnye byvshego SSSR [Amphibians of the former USSR]. 2nd edition. KMK Scientific Press, Moscow (in Russian).

Kuzmin, S. L., Pupina, A., Pupins, M., \& Trakimas, G. (2008). Northern border of the distribution of the red-bellied toad (Bombina bombina). Zeitschrift für Feldherpetologie, 15, 215-228.

Lebedinskii, A. A., Noskova, O. S., \& Dmitriev, A. I. (2019). Post-fire recovery of terrestrial vertebrates in the Kerzhensky State Nature Biosphere Reserve (Central Volga Region, Russia). Nature Conservation Research, 4(Suppl. 1), 45-56.

Leon-Regagnon, V., \& Brooks, D. (2003). Molecular phylogeny of Haematoloechus Looss, 1899. Journal of Parasitology, 89(6), 1206-1211. 
Litvinchuk, S. N., \& Kidov, A. A. (2018). Distribution and conservation status of the Caucasian parsley frog, Pelodytes caucasicus (Amphibia: Anura). Nature Conservation Research, 3(Suppl. 1), 51-60.

Litvinov, A., Komeva, L., Gerasimov, Y., Kitaev, A., Seletkova, E., Okhapkin, A., Mineeva, N., Lazareva, V., Dvinskikh, S., Alexevnina, M., Zinovev, E., Shurganova, G., Papchenkov, V., Shcherbina, G., Noskov, V., Presnova, E., \& Baklanov, M. (2009). Rivers of Europe. The Volga River Basin. Elsevier, Academic Press, London.

Maguza, V. S. (1973). Gel'minty amfibij Poles'ya Ukrainy [Helminths of amphibians from Polesie region of Ukraine]. Kiev State University, Kiev (in Russian).

Meurling, S. (2019). The response in native wildlife to an invading pathogen: Swedish amphibians and Batrachochytrium dendrobatidis. Acta Universitatis Upsaliensis, Uppsala.

Moravec, F., \& Vojtkova, L. (1975). Variabilität von zwei Nematodenarten Oswaldocruzia filiformis (Goeze, 1782) und Oxysomatium brevicaudatum (Zeder, 1800) [Variability of two nematode species Oswaldocruzia filiformis (Goeze, 1782) and Oxysomatium brevicaudatum (Zeder, 1800)]. Der gemeinsamen Parasiten der Europäischen Amphibien und Reptilien. Volume 2(5). Universita J. E. Purkyně, Brno. Pp. 61-76 (in German)

Narayan, E., Molinia, F., \& Hero, J.-M. (2011). Absence of invasive Chytrid fungus (Batrachochytrium dendrobatidis) in native Fijian ground frog (Platymantis vitiana) populations on Viwa-Tailevu, Fiji Islands. Acta Herpetologica, 6(2), 261-266.

Neuhaus, W. (1940). Entwicklung und Biologie von Pleurogenoides medians Olss. Zoologische Jahrbucher, Abteilung für Systematic, 74, $207-242$ (in German).

Odening, K. (1966a). Der Lebenszyklus des Trematoden Strigea strigis (Schrank) im Raum Berlin [The life cycle of the trematode Strigea strigis (Schrank) in the Berlin area]. Monatlichen Beitrag von der Deutschen Akademie der Wissenschaften zu Berlin, 8, 696-697 (in German).

Odening, K. (1966b). Der Lebenszyklus des Trematoden Strigea sphaerula (Rudolphi) im Raum Berlin [The life cycle of the trematode Strigea sphaerula (Rudolphi) in the Berlin area]. Monatlichen Beitrag von der Deutschen Akademie der Wissenschaften zu Berlin, 8, 695-696 (in German).

Odening, K. (1967). Die lebenszyklen von Strigea falconispalumbi (Viborg), S. strigis (Schrank) und S. sphaerula (Rudolphi) (Trematoda, Strigeida) im Raum Berlin [The life cycles of Strigea falconispalumbi (Viborg), S. strigis (Schrank) and S. sphaerula (Rudolphi) (Trematoda, Strigeida) in the Berlin area]. Zoologische Jahrbucher, Abteilung für Systematic, 94, 1-67 (in German).

Olson, P. D., Cribb, T. H., Tkach, V. V., Bray, R. A., \& Littlewood, D. T. J. (2003) Phylogeny and classification of the Digenea (Platyhelminthes: Trematoda). International Journal of Parasitology, 33, 733-755.

Pigulevsky, S. V. (1952). Semejstvo Gorgoderidae Looss, 1901 [The family Gorgoderidae Looss, 1901]. In: Trematodes of animals and human. Basics of trematodology. Volume 7(1). USSR Academy of Sciences Publishing House, Moscow, Leningrad. Pp. 605-760 (in Russian).

Pigulevsky, S. V. (1953). Semejstvo Gorgoderidae Looss, 1901 [The family Gorgoderidae Looss, 1901]. In: Trematodes of animals and human. Basics of trematodology. Volume 8(2). USSR Academy of Sciences Publishing House, Moscow, Leningrad. Pp. 251-615 (in Russian).

Pupina, A., Pupins, M., Nekrasova, O., Tytar, V., Kozynenko, I., \& Marushchak, O. (2018). Species distribution modelling: Bombina bombina (Linnaeus, 1761) and its important invasive threat Perccottus glenii (Dybowski, 1877) in Latvia under global climate change. Journal of Environmental Research, Engineering and Management, 74(4), 79-86.

Ruchin, A. B., Kirillov, A. A., Chikhlyaev, I. V., \& Kirillova, N. Y. (2016). Paraziticheskie chervi nazemnykh pozvonochnykh Mordovskogo zapovednika [Parasitic worms of terrestrial vertebrates in Mordovia Nature Reserve (annotated list of species)]. Moscow (in Russian)

Ryzhikov, K. M., Sharpilo, V. P., \& Shevchenko, N. N. (1980). Gel'minty amfibij fauny SSSR [Amphibian helminths of the USSR fauna]. Nauka, Moscow (in Russian).

Savinov, V. A. (1963). Nekotorye novye ehksperimental'nye dannye o rezervuarnom parazitizme u nematod [Some new experimental data on the reservoir parasitism of nematodes]. In: Proceedings of the scientific conference of the AllUnion Society of Helminthologists. Part 2. USSR Academy of Sciences, Moscow. Pp. 73-75 (in Russian).

Sawyer, R. T. (1986). Leech biology and behavior. Vol. I-III. Clarendon Press, Oxford.

Sayim, F. (2010). Toxicity of trifluralin on the embryos and larvae of the red-bellied toad, Bombina bombina. Turkish Journal of Zoology, 34, 479- 486.

Schaake, M. (1931). Infectionsmodus und Infectionsweg der Rhabdias bufonis Schrank (Angiostomum nigrovenosum) und die Metamorphose des Genitalapparaten der Hermafroditischen Generation [Mode and route of infection of the Rhabdias bufonis Schrank (Angiostomum nigrovenosum) and the metamorphosis of the genital apparatus of the hermaphroditic generation]. Zeitschrift für Parasitekunde, 3(4), 517-648 (in German).

Schotthoefer, A. M., Koehler, A. V., Meteyer, C. U., \& Cole, R. A. (2003). Influence of Ribeiroia ondatrae (Trematoda: Digenea) infection on limb development and survival of northern leopard frogs (Rana pipiens): Effects of host stage and parasite-exposure level. Canadian Journal of Zoology, 81, 1144-1153.

Sewell, T. R., Longcore, J., \& Fisher, M. C. (2021). Batrachochytrium dendrobatidis Trends in Parasitology, 37, 10

Shaldybin, S. L. (1977). K parazitofaune beskhvostykh amfibij Volzhsko-Kamskogo zapovednika [On the parasitic fauna of anurans in Volga-Kama Nature Reserve] In: Questions of herpetology. Nauka, Leningrad. Pp. 228-230 (in Russian).

Sharpilo, V. P. (1976). Paraziticheskie chervi presmykayushhikhsya fauny SSSR [Parasitic worms of reptile fauna of the USSR]. Naukova Dumka, Kiey (in Russian).

Shevchenko, N. N. (1965). Gel'mintofauna biotsenoza Severskogo Dontsa i puti ee tsirkulyatsii v srednem techenii reki [Helminth fauna of Seversky Donets biocoenosis and ways of its circulation in the middle reaches of the river]. Kharkov State University, Kharkov (in Russian).

Shevchenko, N. N., \& Vergun, G. I. (1960). Rasshifrovka tsikla razvitiya trematody Astiotrema monticelli Stossich, 1904 [Deciphering the cycle of development of rematode Astiotrema monticelli Stossich, 1904]. Reports of the USSR Academy of Sciences, 130(4), 949-952 (in Russian).

Shimalov, V. V. (2008). Gel'mintofauna zemnovodnykh (Vertebrata, Amphibia) presmykayushhikhsya (Vertebrata, Reptilia) v landshaftnom zakaznike "Bugskij" (Belarus) [The helminthofauna of amphibians (Vertebrata, Amphibia) and reptiles (Vertebrata, Reptilia) in the Landscape Reserve "Bugskiy" (Belarus)] Brest University Bulletin, 31, 80-87 (in Russian).

Shimalov, V. V. (2009). Gel'mintofauna amfibij (Vertebrata: Amphibia) v Respublike Belarus [Helminth fauna of amphibians (Vertebrata: Amphibia) in the Republic of Belarus]. Parazitologyia, 43(2), 118-129 (in Russian).

Skrjabin, K. I. (1928). Metod polnogo gel'mintologicheskogo vskrytiya pozvonochnykh, vklyuchaya cheloveka [Method of complete helminthological autopsy of vertebrates, including man]. Moscow State University, Moscow (in Russian).

Skrjabin, K. I. (1949). Podotryad Paramphistomatata (Szidat, 1936) Skrjabin et Schulz 1937. Trematody zhivotnykh i cheloveka. Osnovy trematodologii. Tom 3 [Suborder Paramphistomatata (Szidat, 1936) Skrjabin et Schulz, 1937. Trematodes of animals and humans. Basics of trematodology. Volume 3]. USSR Academy of Sciences Publishing House, Moscow, Leningrad (in Russian).

Skrjabin, K. I., \& Antipin, D. N. (1962). Supersemejstvo Plagiorchioidea Dollfus, 1930. Chast' 5. Semejstvo Plagiorchidae Lühe, 1901 [Superfamily Plagiorchioidea Dollfus, 1930. Part 5. Family Plagiorchidae Lühe, 1901]. Trematodes of animals and human. Basics of trematodology. Volume 20. USSR Academy of Sciences Publishing House, Moscow. Pp. 46-163 (in Russian).

Skrjabin, K. I., Shikhobalova, N. P., \& Lagodovskaya, E. A. (1961). Osnovy nematodologii. Tom 10. Oksiuraty zhivotnykh i cheloveka. Chast' 2 [Basics of nematodology. Volume 10. Oxyurata of animals and humans. Part 2]. USSR Academy of Sciences Publishing House, Moscow (in Russian).

Smirnova, M. I., \& Sizova, V. G. (1978). Gel'mintofauna vodnykh amfibij zelyonoj zony g. Kazani [Helminth fauna of aquatic amphibians of the green zone of Kazan city]. In: Natural Resources of the Volga-Kama Region. Issue 5. Kazan State University, Kazan. Pp. 194-201 (in Russian).

Smirnova, M. I., Gorshkov, P. K., \& Sizova, V. G. (1987). Gel'mintofauna beskhvostykh zemnovodnykh v Tatarskoj respublike [Helminth fauna of tailless amphibians in Tatarstan Republic]. Institute of Biology of Academy of Sciences of the USSR, Kazan (in Russian).

Stark, T., Brouwer, D., Ploeg, R., \& Lenders, T. (2017). First record of phoresy or possible parasitism by the fresh water leech Helobdella stagnalis (Glossiphoniidae) on Lissotriton helveticus (Caudata: Salamandridae) in the Netherlands. Herpetology Notes, 10, 717-719.

Sudarikov, V. E. (1960). Otryad Strigeidida (La Rue, 1926) Sudarikov, 1959 [Order Strigeidida (La Rue, 1926) Sudarikov, 1959]. Trematodes of animals and human. Basics of trematodology. Volume 17(2). USSR Academy of Sciences Publishing House, Moscow. Pp. 157-533 (in Russian).

Sudarikov, V.E. (1984). Trematody fauny SSSR. Strigeidy [Trematodes of the fauna of the USSR. Strigeides]. Nauka, Moscow (in Russian).

Sudarikov, V. E., Shigin, A. A., Kurochkin, Y. V., Lomakin, V. V., Stenko, R. P., \& Yurlova, N. I. (2002). Metatserkarii trematod - parazity presnovodnykh gidrobiontov Tsentral'noj Rossii [Metacercariae of trematodes - parasites of freshwater aquatic organisms in Central Russia]. Nauka, Moscow (in Russian).

Svinin, A. O., Bashinskiy, I. V., Litvinchuk, S. N., Ermakov, O. A., Ivanov, A. Y Neymark, L. A., Vedernikov, A. A., Osipov, V. V., Drobot, G. P., \& Dubois, A. (2020a). Strigea robusta causes polydactyly and severe forms of Rostand's anomaly $\mathrm{P}$ in water frogs. Parasites Vectors, $13,381$.

Svinin, A. O., Ermakov, O. A., Litvinchuk, S. N., \& Bashinskiy, I. V. (2020b). Sindrom anomalii $\mathrm{P}$ u zelenykh lyagushek: Istoriya otkrytiya, morfologicheskie osobennost i vozmozhnye prichiny vozniknoveniya [The anomaly $\mathrm{P}$ syndrome in green frogs: The history of discovery, morphological features and possible causes]. Proceedings of the Zoological Institute RAS, 324(1), 108-123 (in Russian).

Szuroczki, D., Vesprini, N. D., Jones, T. R. B., Spencer, G. E., \& Carlone, R. L. (2011). Presence of Ribeiroia ondatrae in the developing anuran limb disrupts retinoic acid levels. Parasitology Research, 110(1), 49-59. 
Thiel, P. H. (1930). Die Entwicklung von Agamodistomum anopheles zum Pneumonoeces variegatus Rud. [The development of Agamodistomum anopheles into Pneumonoeces variegatus Rud.]. Zentralblatt fur Bakteriologie Parasitenkunde Infektions, 117, 103-112 (in German).

Tiberti, R., \& Gentilli, A. (2010). First report of leech Helobdella stagnalis (Rhyncobdellida: Glossiphoniidae) as a parasite of an anuran amphibian. Acta Herpetologica, 5(2), 255-258.

Tkach, V. V., Pawlowski, J., Mariaux, J., \& Swiderski, Z. (2001). Molecular phylogeny of the suborder Plagiorchiata and its position in the system of Digenea. In: Interrelations of the Platyhelminthes. Taylor \& Francis, London. Pp. 186-193.

Tytar, V., Nekrasova, O., Pupina, A., Pupins, M., \& Oskyrko, O. (2018). Long-term bioclimatic modelling the distribution of the fire-bellied toad, Bombina bombina (Anura, Bombinatoridae), under the influence of global climate change. Vestnik Zoologii, 52(4), 341-348.

Vedernikov, A. A., Svinin, A. O., Ermakov, O. A., Chelyadnikova, Y. A., Musatov, G. A., \& Drobot, G. P. (2020). Granulomatous inflammations in the intestine of Pelophylax ridibundus (Anura: Ranidae) caused by Brandesia turgida (Plathelminthes: Digenea). Nature Conservation Research, 5, 72-76.
Vojtková, L. (1974). Motolice obojživelníků ČSSR. I. Dospělé motolice [Trematodes of amphibians of Czechoslovakia. I. Adult trematodes]. Universita J. E. Purkyně, Brno (in Czech).

Vojtková, L., \& Roca, V. (1994). Parasites of the frogs and toads in Europe. Part II: Trematoda. Revista Española de Herpetología, 8, 7-18.

Vojtková, L., \& Roca, V. (1996). Parasites of the frogs and toads in Europe. Part III: Nematoda, Cestoda, Acanthocephala, Hirudinea, Crustacea and Insecta. Revista Española de Herpetología, 10, 13-27.

Wake, D. B., \& Vredenburg, V. T. (2008). Are we in the midst of the sixth mass extinction? A view from the world of amphibians. Proceedings of the National Academy of Sciences, 105, 11466-11473.

Yumagulova, G. R. (1999). K izucheniyu nematody Cosmocercooides skrjabini (Ivanitzky, 1940) [On the study of nematode Cosmocercooides skrjabini (Ivanitzky, 1940)]. Results of biological research of the Bashkir State University for 1998. Bashkir State University, Ufa. Pp. 12-13 (in Russian).

Yumagulova, G. R. (2000). Gel'minty amfibij Yuzhnogo Urala [Helminths of amphibians of the Southern Urals]. Bashkir State University, Ufa (in Russian).

Zimić, A. (2015). Commensalism, predation or parasitism: First report of the leech Helobdella stagnalis Linnaeus, 1758 on yellow-bellied toad, Bombina variegata (Linnaeus, 1758). Ecologica Montenegrina, 2(1), 62-63. 